\title{
Multiple Histological Subtypes of Dermatofibrosarcoma Protuberans Occurring in the Same Tumor
}

\author{
C. SOCOLIUC ${ }^{1,2}$, SABINA ZURAC $^{1,2}$, R. ANDREI $^{1}$, FLORICA STĂNICEANU ${ }^{1,2}$ \\ 1“Colentina” University Hospital, Department of Pathology \\ ${ }^{2}$ University of Medicine and Pharmacy, Department of Pathology, Bucharest, Romania
}

\begin{abstract}
Dermatofibrosarcoma protuberans (DFSP) represents a low-grade cutaneous sarcoma which may have different histological aspects, presenting as a fibrosarcomatous, pigmented, juvenile, myxoid, atrophic, sclerosing or myoid lesion. Some of these subtypes may occur isolated or in association with one of the others creating hybrid lesions. We present the case of a 66 years old woman having a $4 \mathrm{~cm}$ diameter tumor located on the abdominal wall. Histopathological examination of the resection specimen revealed areas of typical DFSP associated with fibrosarcomatous transformation, myoid and myxoid areas. Also, focally, pleomorphic tumor cells and foreign-body type multinucleated giant cells were observed. Immunostains revealed CD34 positivity in typical DFSP and myxoid areas with negative staining of some of the tumor cells in fibrosarcomatous areas and negative staining of myoid areas. Smooth muscle actin was positive in myoid areas. The nature of myoid fascicles in DFSP is a matter of debate, being uncertain whether these represent a type of tumor differentiation or a reactive myoid proliferation. In this particular case, finding the association of myoid cells with blood vessel walls sustains their reactive nature. We present the morphological aspects of the different areas of the tumor with emphasis on differential diagnostic problems and clinical implications.
\end{abstract}

Key words: Dermatofibrosarcoma protuberans, fibrosarcomatous, juvenile, giant-cell fibroblastoma, myxoid, myoid.

Dermatofibrosarcoma protuberans (DFSP) represents a low-grade cutaneous sarcoma, locally aggressive, having a low risk of distant metastasis [1]. The "protuberans" designation is based on the clinical aspect of advanced lesions presenting usually as prominent, indurated tumor nodules [2]. Other clinical variants exist, especially in early lesions [3]: angioma-like, morphea-like and atrophoderma-like potentially leading to confusions with a vascular tumor, morphea, atrophoderma, a scar, dermatofibroma or a basal cell carcinoma.

DFSP occurs more frequently in young and middle-aged adults, prevailing in the 20-50 years age group [4]. Although rare it also occurs in children with even congenital lesions being reported, suggesting that some adult cases may represent slow-growing lesions beginning in childhood $[5,6]$.

The tumor has a predilection for the trunk, proximal extremities and head and neck region [7, 8] being rare on acral locations [9].

There have been described several histopathological variants of DFSP including fibrosarcomatous, pigmented DFSP or Bednar tumor, myxoid, juvenile DFSP or giant cell fibroblastoma, atrophic, sclerosing and myoid. Some of these variants may occur in pure form or admixed with one of the others creating hybrid lesions [10]. These have little clinical differences but they have a characteristic 
histological aspect, making their acknowledgement essential for establishing a correct diagnosis of DFSP in particular situations

\section{CASE REPORT}

A 66 years old woman presented to the General Surgery Department of our hospital for the treatment of an ulcerated tumor located on the abdominal wall. Grossly, the resection specimen consisted of a 10/6 cm skin fragment with a centrally located tumor having a $4 \mathrm{~cm}$ diameter. On sectioning the tumor was apparently well delineated, pearl-white in color and of firm consistency. Several parallel sections were performed longitudinally to demonstrate the extension into surrounding tissues and the relationship of the tumor to lateral and profound resection margins. The first and last longitudinally sectioned fragments were recut perpendicularly to demonstrate the tumor extension towards lateral margins following a transverse axis. Representative fragments were fixed in $10 \%$ buffered formalin and embedded in paraffin. The $3 \mu \mathrm{m}$ thick tissue sections obtained were stained with hematoxylin and eosin and also with FontanaMasson stain for melanin pigment and Perls Prussian blue stain for hemosiderin. Immunohistochemical stains used antibodies against CD34, CD31, S100, smooth muscle actin (SMA) and p53. Histopathologic examination of hematoxylin-eosin stained slides revealed a dermal-based neoplastic proliferation with deep extension into hypodermis and fascial tissue. A grenz zone of uninvolved papillary dermis was noted on the majority of sections, with small areas of tumor extending up to the epidermis which demonstrated slight full-thickness acanthosis (Fig. 1). The neoplastic proliferation was predominantly arranged in short intersecting fascicles or radiating from a central point represented by a small vessel or fibrous tissue, creating a storiform pattern. These fascicles infiltrated the hypodermis isolating adipocytes in a honeycomb pattern (Fig. 2). At the periphery, isolation of thick dermal collagen bundles (Fig. 3) and of cutaneous adnexa was seen. The tumor cells were spindle-shaped with indistinct borders, pink cytoplasm and relative uniform nuclei with open chromatin. The mitotic activity was low in these areas with a maximum of 4 mitoses/ 10 HPF. In deeper portions of the tumor there were present very rare hypertrophied, hyperchromatic nuclei with an irregular contour creating focally a pleomorphic appearance of the tumor proliferation (Fig. 4). Besides this pattern of proliferation described above, three others were observed. First, an important area of the tumor approximating $40 \%$ of the examined tissue was represented by a higher cellularity proliferation of spindle cells with an increased number of mitotic figures up to 10 mitoses/10 $\mathrm{HPF}$, arranged in fascicles oriented at steep angles to each other, creating a "herring-bone" aspect, resembling fibrosarcoma (Fig. 5). The transition from typical areas described above was gradual and nuclear atypia was slightly higher with nuclei showing coarse chromatin. Second, at low-power examination, abrupt transition to more eosinophiliclooking areas was seen. High power examination revealed variable length fascicles intersected at various, sometimes right, angles, composed of elongated tumor cells with abundant eosinophilic, fibrillary cytoplasm and elongated, cigar-shaped nuclei having finely granular chromatin, resembling smooth muscle cells. No cellular atypia or mitoses were seen in these myoid areas. Stromal collagen was better represented contributing to the overall eosinophilia. Myoid fascicles were seen in profound or central areas, sometimes associated around muscular-wall vessels (Fig. 6). An interesting finding was the presence of giant cells in myoid areas, having hypereosinophilic cytoplasm and multiple monomorphic, smooth-chromatin nuclei distributed in a random fashion reminiscent of "foreign-body" type giant cells (Fig. 7). These cells were located in areas of tissue rarefaction creating pseudovascular spaces or around small, ectatic capillaries. The 
third category of different areas was hypocellular areas located immediately beneath the epidermis or in deep regions (Fig. 8). These were composed of a haphazard proliferation of monotonous spindle cells distributed in a pale-basophilic, myxoid stroma. Immunohistochemical stains (Fig. 9) revealed diffuse CD34 positivity in the majority of tumor cells in typical storiform areas and slightly less in myxoid areas. Focally, CD34 positivity was lost in fibrosarcomatous areas. CD34 expression was absent in myoid areas, including the multinucleated tumor cells described. SMA was negative in storiform, fibrosarcomatous and myxoid areas but it was positive in myoid fascicles. S100 and CD31 were negative with positive internal control. P53 stain revealed increased number of positive cells in fibrosarcomatous areas, with approximately $30 \%$ of tumor cells stained. On the basis of the histopathologic and immunohistochemical findings, a diagnosis of dermatofibrosarcoma protuberans with fibrosarcomatous transformation was made, having tumor-free resection margins.

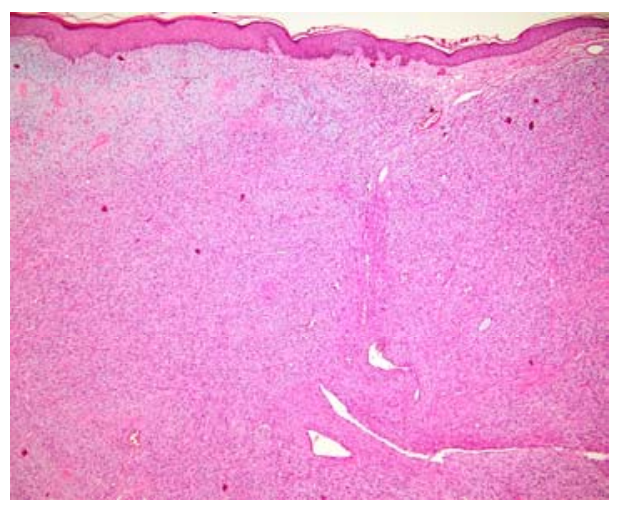

Figure 1. Slight epidermal acanthosis in areas where the grenz zone is lost $(\mathrm{HE} \times 40)$.
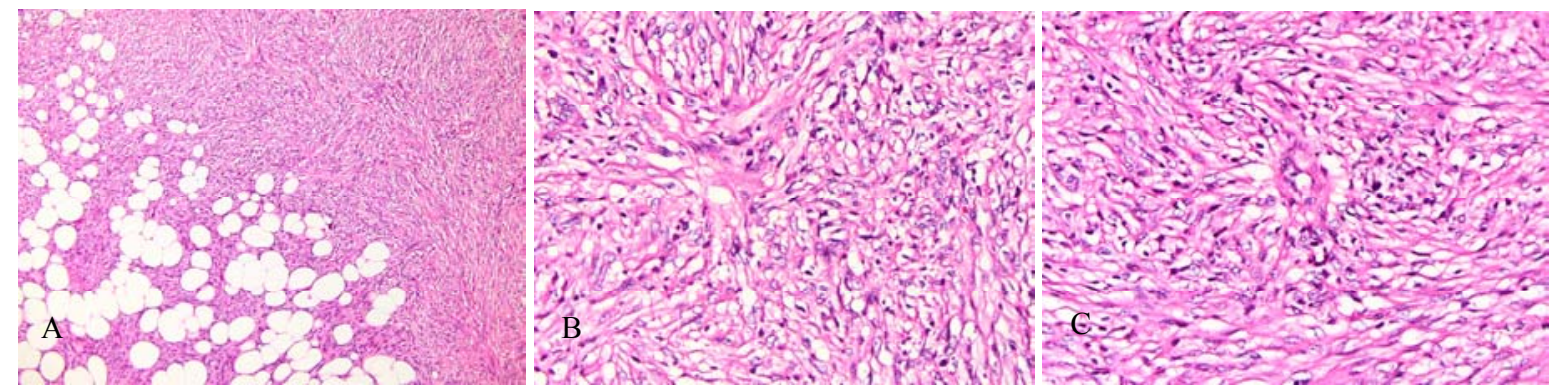

Figure 2. A. Storiform proliferation of spindle cells infiltrating the hypodermis in a honeycomb pattern $(\mathrm{HE} \times 100)$;

B, C. Storiform proliferation with tumor cells radiating around a central "hub", having uniform nuclei with open chromatin $(\mathrm{HE} \times 400)$.

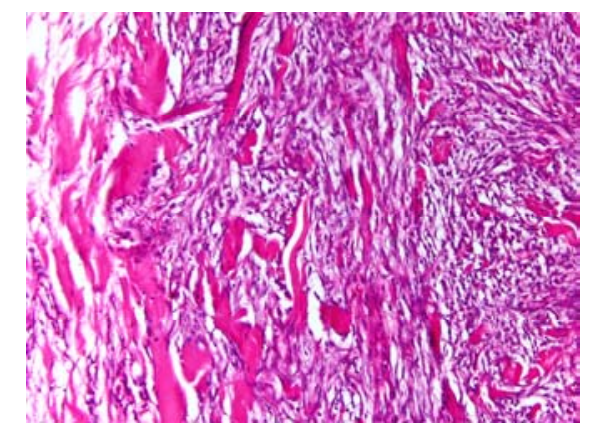

Figure 3. Isolation of thick dermal collagen bundles at the tumor periphery $(\mathrm{HE} \times 200)$. 


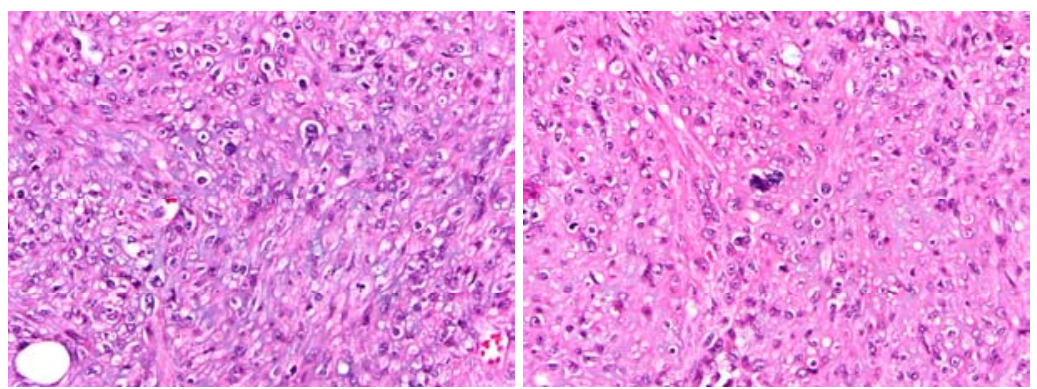

Figure 4. Rare hypertrophied, hyperchromatic nuclei with an irregular contour

in deeper areas of the tumor $(\mathrm{HE} \times 400)$.
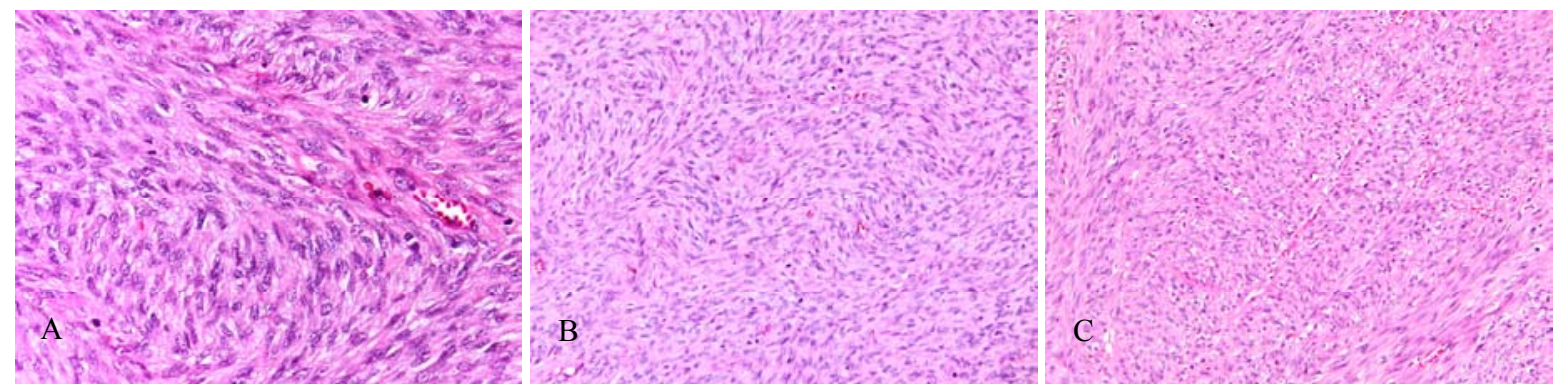

Figure 5. Fibrosarcomatous areas with fascicular growth pattern, increased atypia and increased number of mitotic figures $(\mathrm{A}-\mathrm{HE} \times 400, \mathrm{~B}, \mathrm{C}-\mathrm{HE} \times 200)$.
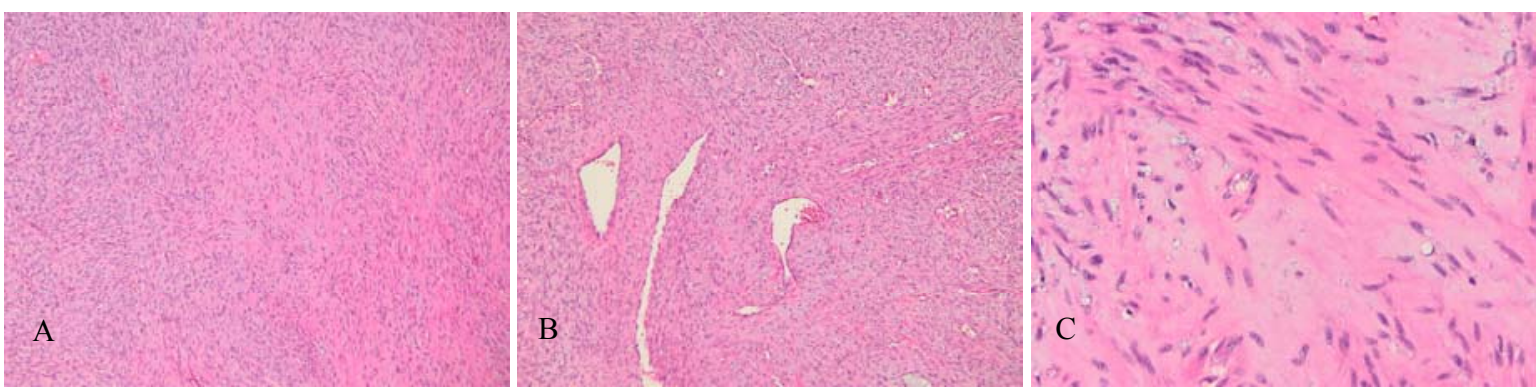

Figure 6 A. Transition to more eosinophilic myoid areas (right) $(\mathrm{HE} \times 100)$;

B. Myoid cells around blood vessels $(\mathrm{HE} \times 100)$;

C. Details of myoid cells in myoid fascicles $(\mathrm{HE} \times 400)$.

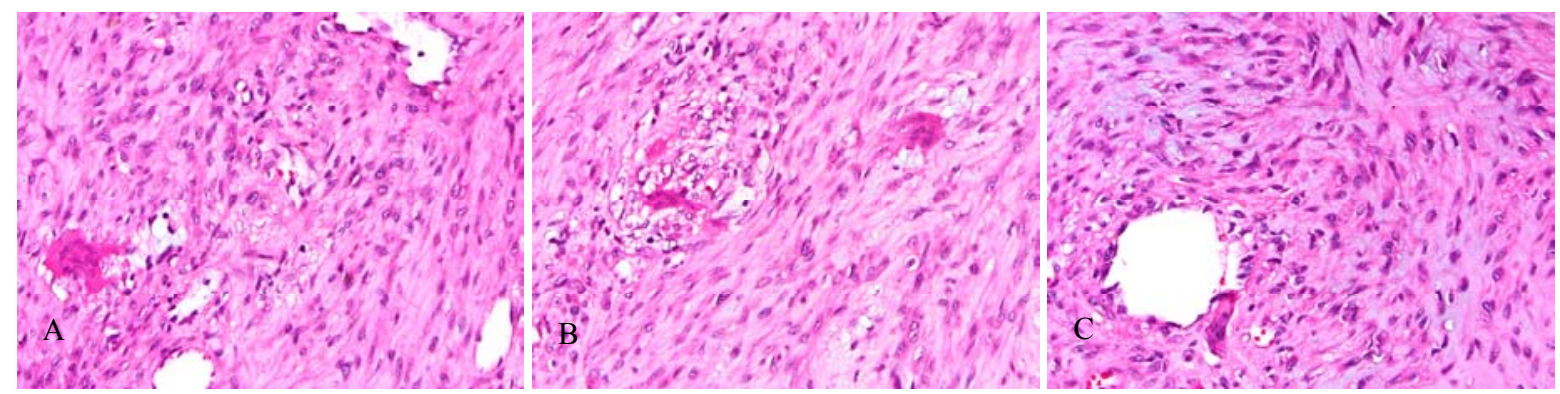

Figure 7. Foreign-body type giant cells located in areas of tissue rarefaction (A, B)

or around blood vessels $(\mathrm{C})(\mathrm{HE} \times 400)$. 


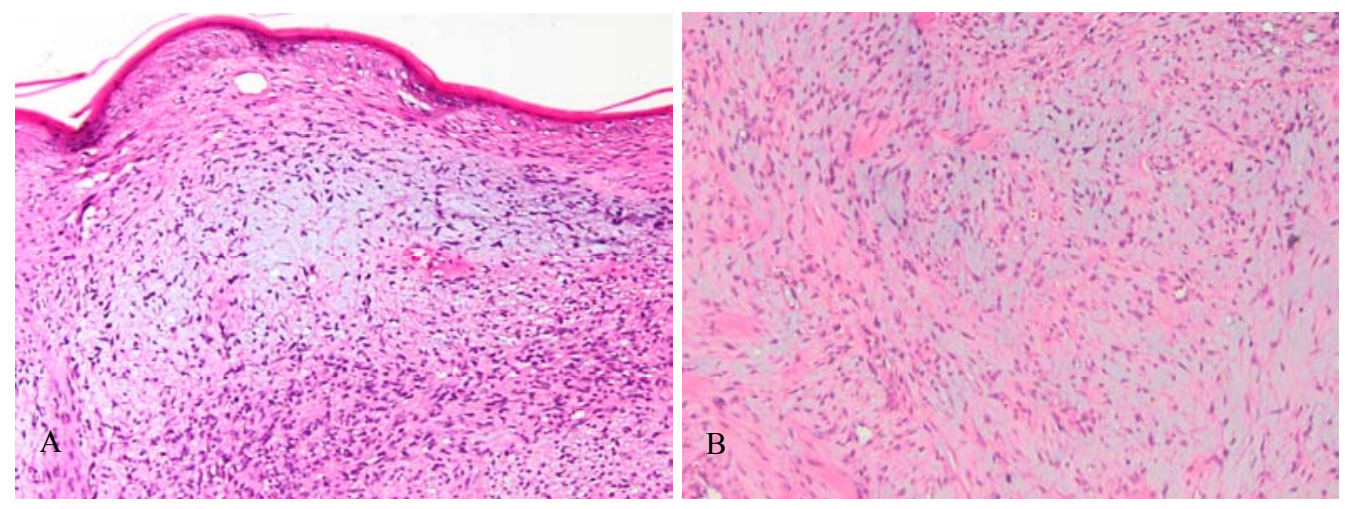

Figure 8 A. Superficial myxoid areas $(\mathrm{HE} \times 200)$;

B. Deep myxoid areas (HE $\times x$ 200).
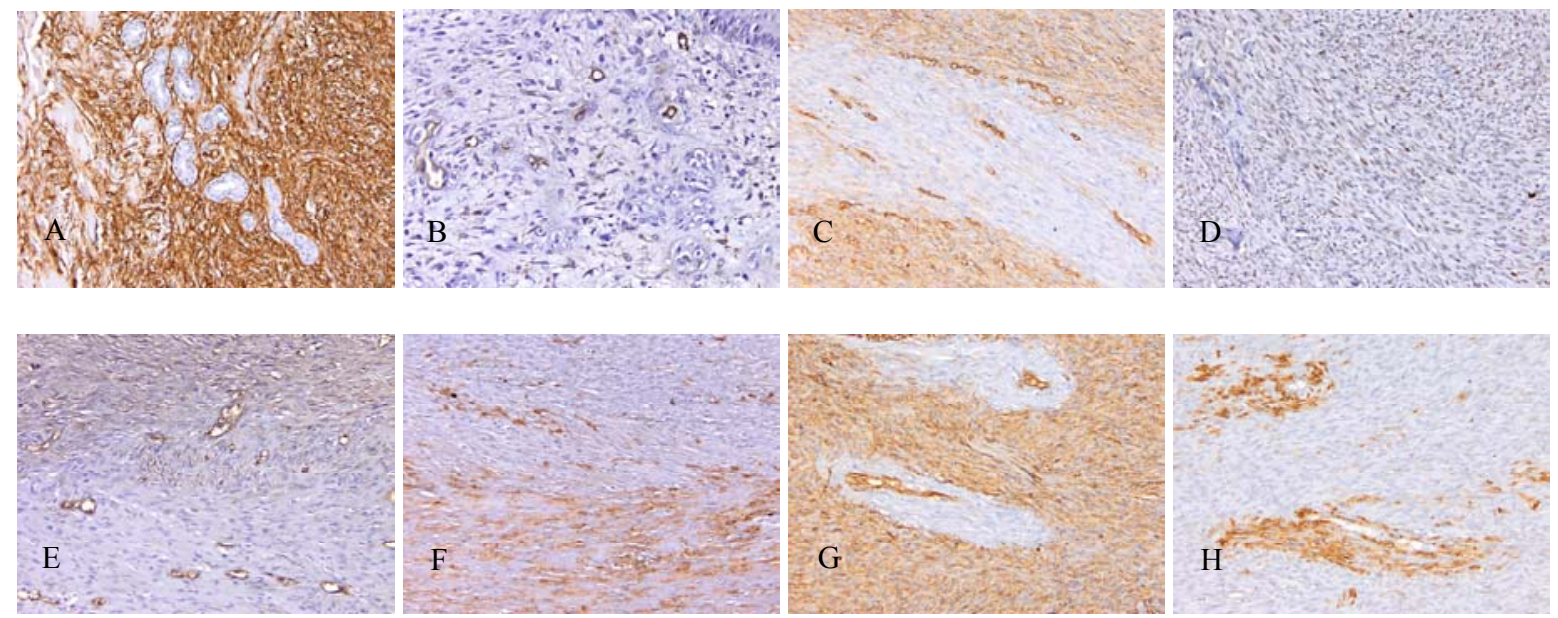

Figure 9 A. CD34 positive tumor cells isolating cutaneous adnexa $(\mathrm{HE} \times 200)$;

B. Faint CD34 positivity in tumor cells from myxoid areas $(\mathrm{HE} \times 400)$;

C. Negative CD34 in fibrosarcomatous areas $(\mathrm{HE} \times 200)$;

D. p53 positive nuclei in fibrosarcomatous areas;

E. CD34 positive tumor cells with negative myoid area $(\mathrm{HE} \times 200)$;

F. SMA positive myoid area with negative tumor cells $(\mathrm{HE} \times 200)$;

G. CD34 negative perivascular myoid cells $(\mathrm{HE} \times 200)$;

H. SMA positive perivascular myoid cells $(\mathrm{HE} \times 200)$.

\section{DISCUSSION}

DFSP presents in typical resection specimens with a fascicular and storiform proliferation of monotonous spindle cells having little atypia and a low number of mitoses, ranging from 1 to 3 per 10 high power fields $[11,12]$. The storiform pattern of growth is considered to be characteristic and is represented by whirling of short chords of tumor cells around a central hub creating a pinwheel appearance. The central hub can be represented, according to Taylor and Helwig, by fibrous tissue, a vessel or by a tumor cell [11]. The proliferation has also a characteristic pattern of infiltration into subcutaneous fat which is one of the most useful features for establishing a diagnosis [10]. Kamino and Jacobson [13] found two main patterns of growth into subcutaneous tissue, a multilayered pattern with infiltrating fascicles of tumor cells oriented parallel to the epidermis leaving among 
them uninvolved bands of fat tissue and a honeycomb pattern with tumor cells infiltrating and isolating adipocytes, as in the case presented. Another characteristic of the infiltrative growth of DFSP is isolation of cutaneous adnexa, without destroying them [14]. All these features help to separate typical DFSP from dermatofibroma, the main differential diagnosis. Dermatofibroma has a haphazard growth pattern with only focal storiform areas and may have only minimal extension into hypodermis along fibrous septa or with a pushing pattern, without creating a honeycomb aspect [15]. Also, it does not isolate cutaneous adnexa but manifests dermal collagen entrapping at the periphery, although this finding can also be observed in DFSP, as in our case. The cellularity is more variable comprising spindle cells, foamy histiocytes, multinucleated giant cells, siderophages and other inflammatory cells which are usually missing from DFSP. The relationship of the tumor with the overlying epidermis can be misleading. The uninvolved papillary dermis (grenz zone) and epidermal hyperplasia generally represent features of dermatofibroma. However, these can be present in DFSP, one study describing epidermal hyperplasia in $73 \%$ of cases, the degree of hyperplasia being inversely related to the distance between the tumor and the epidermis [16]. In the case presented, the epidermis was normal in areas with conserved grenz zone but became slightly achantotic when the tumor spanned the entire thickness of the papillary dermis, sustaining this observation. In difficult cases CD34 immunostain can help establishing the correct diagnosis being diffusely positive in DFSP and negative or, at most, focally positive in dermatofibroma [17].

Fibrosarcomatous transformation of DFSP (FS-DFSP) was first described in 1951 by Penner who presented a case of metastasizing DFSP containing areas indistinguishable from fibrosarcoma [18]. The definition of this transformation is morphologic representing a transition of typical DFSP to a fascicular proliferation of spindle cells with increased cytologic atypia and usually increased mitotic activity [19] - 10 mitoses/10HPF in our case. The presence of highly pleomorphic cells could signify transformation to pleomorphic sarcoma, which behaves aggressively [19]. However, their rarity in our case and the nuclear chromatin aspect more likely represented degenerative atypia. For diagnosing FS-DFSP, the fibrosarcomatous proliferation should occupy at least $5-10 \%$ of the tumor [20]. Since the original report by Penner this transformation was thought to be associated with an aggressive clinical course, a large study showing higher risk for local recurrences and metastasis in FS-DFSP compared to DFSP [21]. However, this finding may not be true due to inclusion in such studies of suboptimal treated patients [22]. In cases where Mohs surgery was applied no recurrences were observed [23]. According to Mentzel et al. [24] CD34 positivity is usually less intense or completely lost in FS areas, possibly explained by the progression of DFSP to CD34 negative fibrosarcoma. Also, p53 staining tends to be positive in FS-DFSP compared to typical DFSP areas [23]. In our case, smaller areas than the total area occupied by the FS-DFSP were seen with complete loss of CD34 and p53 expression was found in up to $30 \%$ of transformed tumor cells.

Myoid areas in DFSP are rare and were observed mostly in association with fibrosarcomatous transformation $[25,26]$. This occurrence was first described independently in 1996 by Calonje and Fletcher [26] and by O'Connell and Trotter [27]. They presented few cases of FS-DFSP which contained fascicles and nodules of spindle cells with eosinophilic cytoplasm and vesicular nuclei resembling smooth muscle cells or myofibroblasts. These cells were negative for CD34 and positive for actins, being considered a form of myoid/myofibroblastic differentiation of tumor cells, sustaining a myofibroblastic origin of DFSP [10]. However, other authors found on serial sectioning that myoid bundles were connected to vessel walls 
probably representing a reactive proliferation of pericytes or smooth muscle cells of the vessel wall [28]. In our case there were present large areas containing myoid fascicles of bland cells without atypia or mitotic activity, lying especially in deep areas of the tumor, isolated or in relation to vessel walls. They were CD34 negative and SMA positive. These aspects sustain a reactive nature of myoid cells rather than a special type of differentiation of tumor cells. Also, in myoid areas, the presence of giant cells raised the possibility of a giant cell fibroblastoma component in the tumor proliferation. Giant cell fibroblastoma is considered to be the juvenile form of DFSP, occurring mainly in children but also in young and older adults [29]. It was first described by Enzinger and Shmookler in 1982 [30]. Its distinctive feature consists of the presence in a spindle cell proliferation of pseudovascular spaces lined by hyperchromatic mono- or multinucleated tumor cells which express CD34 [19]. However, in our case, although the giant cells were associated to pseudovascular or vascular spaces they had bland features, lacking hyperchromasia and being CD34 negative, resembling foreign-body type giant cells. This way, they could represent a type of connective tissue response to the locally aggressive DFSP, as was suggested by other authors [31] who found giant-cell fibroblastoma-like areas in a retroperitoneal malignant hemangiopericytoma.

Myxoid DFSP was first described in 1983 by Frierson and Cooper [32]. To classify as myxoid DFSP, the tumor must contain a greater than $50 \%$ of myxoid areas [33], represented by a loose proliferation of spindle cells set in an abundant pale-basophilic stroma containing hyaluronic acid. The tumor cells stain positive for CD34 in the majority of cases [34, 35], with rare cases of negative staining reported [36]. In the lesion described, myxoid areas were present in superficial subepidermal regions of the tumor, but also in deeper areas, intermingled with myoid bundles. The myxoid areas could raise problems of differential diagnosis especially when superficially located, in case of small biopsies. As the first authors to describe this lesion noted, the most useful clues for a correct diagnosis were subtle radial arrangement of tumor cells and infiltration of subcutaneous fat. However, this later aspect is most likely to be absent from superficial biopsies. In this situation, immunostains may be useful. The stains we performed showed in subepidermal myxoid areas low-intensity positivity for CD34 in tumor cells and negativity for CD31, SMA and S100. This pattern will help exclude a limited number of CD34 negative malignancies such as myxoid liposarcoma and myxoid synovial sarcoma. For other entities in the differential diagnosis which may express CD34, careful histologic examination or supplementary immunostains may be needed. Low-grade myxofibrosarcoma has a characteristic curvilinear vasculature, occasional pleomorphic cells, and focal SMA positivity. Low-grade fibromyxoid sarcoma has alternating myxoid and fibrotic areas, showing characteristic MUC4 positivity. Myxoid solitary fibrous tumor is usually deep seated, has a reticular growth pattern and is positive for CD99 and bcl-2. Myxoid neurofibroma has small ondulating/ angulated spindle cells, the majority of which are S100 positive. Myxoid perineurioma may arise in the dermis, has a whorled or lamellar growth pattern and tumor cells are EMA positive. Superficial acral fibromyxoma arises on the digits while DFSP is rare in this location and may be EMA positive. Superficial angiomyxoma shares with DFSP similar clinical features arising in middle-aged adults and being located more frequently on the trunk and head and neck. Subtle histological clues for this diagnosis may be the presence of scattered neutrophils among tumor cells and entrapped strands of squamous epithelium within the lesion [37].

\section{CONCLUSION}

Taking into account the existence of various histologic subtypes of DFSP is important for 
correct recognition of this versatile tumor and for differentiating it from possible more aggressive lesions or from other benign lesions, avoiding under- or overtreatment. Fibrosarcomatous transformation is particularly important to recognize because of the more aggressive clinical course especially in case of suboptimal excision. Although the various subtypes have raised still unanswered questions concerning the cell of origin in DFSP, the occurrence of multiple histological aspects in the same lesion sustains the relationship between these variants, ascertaining that they represent an expression of the same pathological process.
Diagnosing typical DFSP is usually straightforward based on the recognition of characteristic pattern of infiltration into subcutaneous fat, entrapping of cutaneous adnexa and CD34 positivity. However, in case of superficial biopsies, establishing a correct diagnosis may be extremely challenging, especially if the excised tissue contains only myxoid areas. In this situation, thorough examinations of multiple sections looking for subtle histological aspects, supplementary immunostains and clinical correlations are needed. Even this way, a definite diagnosis may still be rendered only on the complete surgical excision specimen.

Dermatofibrosarcomul protuberans reprezintă un sarcom cutanat de grad jos care poate îmbrăca diferite aspecte histopatologice, prezentându-se ca variantă fibrosarcomatoasă, pigmentată, juvenilă, mixoidăa, atrofică, sclerozantă sau mioidă. Unele dintre aceste subtipuri pot fi întâlnite izolat sau asociate unele cu celelalte dând naştere unor leziuni hibride. Prezentăm cazul unei paciente în vârstă de 66 de ani, cu o leziune tumorală de $4 \mathrm{~cm}$ diametru localizată pe peretele abdominal. Examenul histopatologic al piesei de excizie chirurgicală a relevat arii tipice de DFSP asociate cu arii de transformare fibrosarcomatoasă, arii mioide şi arii mixoide. De asemenea, focal, au fost remarcate celule tumorale cu aspect pleomorf şi celule gigante multinucleate de tip „corp străin”. Testele imunhistochimice au relevat pozitivitate pentru CD34 în ariile de DFSP tipic şi ariile mixoide şi absența pozitivității în unele celule tumorale fibrosarcomatoase şi în ariile mioide. Natura fasciculelor mioide din DFSP este considerată încă incertă, nefiind sigur dacă acestea reprezintă un tip particular de diferențiere tumorală sau o proliferare mioidă reactivă. In acest caz particular, observarea asocierii dintre celulele mioide şi pereții vasculari susține natura lor reactivă. Prezentăm aspectele morfologice ale diferitelor zone tumorale subliniind problemele de diagnostic diferențial şi implicațiile clinice.

Corresponding author: Sabina Zurac, "Colentina” University Hospital, Department of Pathology,

21 Stefan cel Mare str., sector 2, 020125, Bucharest, Romania,

Tel. +40213173245 , Fax +40213165512

E-mail: sabina_zurac@yahoo.com

\section{REFERENCES}

1. Mentzel T., Pedeutour F., Lazar A., Coindre J.-M., Dermatofibrosacoma protuberans. In: WHO Classification of Tumours of Soft Tissue and Bone (Fletcher, C. D.M., Bridge, J.A., Hogendoorn, P., Mertens, F. Eds), IARC WHO Classification of Tumours, No 5, IARC, 2013, p. 77-79. 
2. Hoffmann E., Uber das knollentreibende fibrosarkom der haut. Dermat. Ztschr., 1925; 43:1-28.

3. Martin L., Piette F., Blanc P., Mortier L., Avril M.F., Delaunay M.M., Dréno B., Granel F., Mantoux F., Aubin F., Sassolas B., Adamski H., Dalac S., Pauwels C., Dompmartin A., Lok C., Estève E., Guillot B., Clinical variants of the preprotuberant stage of dermatofibrosarcoma protuberans. Br J Dermatol. 2005 Nov; 153(5):932-6.

4. Akram J., Wooler G., Lock-Andersen J., Dermatofibrosarcoma protuberans: clinical series, national Danish incidence data and suggested guidelines. J Plast Surg Hand Surg. 2014 Feb; 48(1):67-73.

5. Tsai Y.J., Lin P.Y., Chew K.Y., Chiang Y.C., Dermatofibrosarcoma protuberans in children and adolescents: Clinical presentation, histology, treatment, and review of the literature. J Plast Reconstr Aesthet Surg. 2014 Sep; 67(9):1222-9.

6. Posso-De Los Rios C.J., Lara-Corrales I., Ho N., Dermatofibrosarcoma protuberans in pediatric patients: a report of 17 cases. J Cutan Med Surg. 2014 May-Jun; 18(3):180-5.

7. Chouk Friaa S., Badri T., Hammami H., Benmously R., Marrak H., Debbiche A., Mokhtar I., Fenniche S., Dermatofibrosarcoma protuberans: a study of 18 cases. Tunis Med. 2013 May; 91(5):342-5.

8. Kim M., Huh C.H., Cho K.H., Cho S., A study on the prognostic value of clinical and surgical features of dermatofibrosarcoma protuberans in Korean patients. J Eur Acad Dermatol Venereol. 2012 Aug; 26(8):964-71.

9. Kricorian G.J., Schanbacher C.F., Kelly A.P., Bennett R.G., Dermatofibrosarcoma protuberans growing around plantar aponeurosis: excision by Mohs micrographic surgery. Dermatol Surg. 2000 Oct; 26(10):941-5.

10. Socoliuc C., Zurac S., Andrei R. Stăniceanu F., A review of morphological aspects in dermatofibrosarcoma protuberans with clinicopathological correlations. Rom. J. Intern. Med., 2014, 52, 4, 239-50.

11. Taylor H.B., Helwig E.B., Dermatofibrosarcoma protuberans. A study of 115 cases. Cancer. 1962 Jul-Aug; 15:717-25.

12. Terrier-Lacombe M.J., Guillou., Maire G., Terrier P., Vince D.R., de Saint Aubain Somerhausen N., Collin F., Pedeutour F., Coindre J.M., Dermatofibrosarcoma protuberans, giant cell fibroblastoma, and hybrid lesions in children: clinicopathologic comparative analysis of 28 cases with molecular data - a study from the French Federation of Cancer Centers Sarcoma Group. Am J Surg Pathol. 2003 Jan; 27(1):27-39.

13. Kamino H., Jacobson M., Dermatofibroma extending into the subcutaneous tissue. Differential diagnosis from dermatofibrosarcoma protuberans. Am J Surg Pathol. 1990 Dec; 14(12):1156-64.

14. Wood L., Fountaine T.J., Rosamilia L., Helm K.F., Clarke L.E., Cutaneous CD34+ spindle cell neoplasms: Histopathologic features distinguish spindle cell lipoma, solitary fibrous tumor, and dermatofibrosarcoma protuberans. Am J Dermatopathol. 2010 Dec; 32(8):764-8.

15. Brenn T., Hornick J. L., Cutaneous Mesenchymal Tumors. In: Practical Soft Tissue Pathology: A Diagnostic Approach (Hornick J. L. Ed) Elsevier Saunders, Philadelphia, 2013, p. 387-394.

16. Carlson J.A., Slominski A., Heasley D., Mihm M.C.; Toda S., Dermatofibrosarcoma Protuberans Can Induce Epidermal Hyperplasia That Is Inversely Related to its Proximity to the Epidermis. Am J Dermatopathol. 1998 Aug; 20(4):428-30.

17. West K.L., Cardona D.M., Su Z., Puri P.K., Immunohistochemical markers in fibrohistiocytic lesions: factor XIIIa, CD34, S-100 and p75. Am J Dermatopathol. 2014 May; 36(5):414-9.

18. Penner D.W. Metastasizing dermatofibrosarcoma protuberans; a case report. Cancer. 1951; 4:1083-6.

19. Miettinen M., Fibroblastic and Myofibroblastic Neoplasms with Malignant Potential. In: Modern Soft Tissue Pathology. Tumors and Non-Neoplastic Conditions (Miettinen M., Ed), Cambridge University Press, Cambridge, 2010, p. 348-59.

20. Weiss S.W., Goldblum J.R., Fibrohistiocytic tumors of intermediate malignancy. In: Enzinger and Weiss's soft tissue tumors (Weiss S.W., Goldblum J.R., Eds) 5th ed Philadelphia: Mosby, Inc; 2008. p. 371-402.

21. Liang C.A., Jambusaria-Pahlajani A., Karia P.S., Elenitsas R., Zhang P.D., Schmults C.D., A systematic review of outcome data for dermatofibrosarcoma protuberans with and without fibrosarcomatous change. J Am Acad Dermatol. 2014 Oct; 71(4):781-6. 
22. Goldblum J.R., Reith J.D., Weiss S.W., Sarcomas arising in dermatofibrosarcoma protuberans: a reappraisal of biologic behavior in eighteen cases treated by wide local excision with extended clinical follow up. Am J Surg Pathol. 2000 Aug; 24(8):1125-30.

23. Llombart B., Monteagudo C., Sanmartín O., López-Guerrero J.A., Serra-Guillén C., Poveda A., Jorda E., Fernandez-Serra A., Pellín A., Guillén C., Llombart-Bosch A., Dermatofibrosarcoma protuberans: a clinicopathological, immunohistochemical, genetic (COL1A1-PDGFB), and therapeutic study of low-grade versus high-grade (fibrosarcomatous) tumors. J Am Acad Dermatol. 2011 Sep; 65(3):564-75.

24. Mentzel T., Beham A., Katenkamp D., Dei Tos A.P., Fletcher C.D., Fibrosarcomatous ("high-grade”) dermatofibrosarcoma protuberans: clinicopathologic and immunohistochemical study of a series of 41 cases with emphasis on prognostic significance. Am J Surg Pathol. 1998 May; 22(5):576-87.

25. Llombart B., Sanmartín O., López-Guerrero J.A., Monteagudo C., Serra C., Requena C., Poveda A., Vistós J.L., Almenar S., Llombart-Bosch A., Guillén C., Dermatofibrosarcoma protuberans: clinical, pathological, and genetic (COL1A1-PDGFB) study with therapeutic implications. Histopathology. 2009 Jun; 54(7):860-72.

26. Calonje E., Fletcher C.D., Myoid differentiation in dermatofibrosarcoma protuberans and its fibrosarcomatous variant: clinicopathologic analysis of 5 cases. J Cutan Pathol. 1996 Feb; 23(1):30-6.

27. O’Connell J.X., Trotter M.J., Fibrosarcomatous dermatofibrosarcoma protuberans with myofibroblastic differentiaion: a histologically distinctive variant [corrected]. Mod Pathol. 1996 Mar; 9(3):273-8.

28. Sanz-Trelles A., Ayala-Carbonero A., Rodrigo-Fernández I., Weil-Lara B., Leiomyomatous nodules and bundles of vascular origin in the fibrosarcomatous variant of dermatofibrosarcoma protuberans. J Cutan Pathol. 1998 Jan; 25(1):44-9.

29. Jha P., Moosavi C., Fanburg-Smith J.C., Giant cell fibroblastoma: an update and addition of 86 new cases from the Armed Forces Institute of Pathology, in honor of Dr. Franz M. Enzinger. Ann Diagn Pathol. 2007 Apr; 11(2):81-8.

30. Shmookler B.M., Enzinger F.M., Giant cell fibroblastoma: a peculiar childhood tumor [Abstract]. Lab Invest. 1982;46:76.

31. Karabela-Bouropoulou V., Liapi-Avgeri G., Mahera H., Magiassis V., Anagnostopoulos D., Bourli A., Kokka H., Savva S., Giant cell fibroblastoma: an entity or a reactive phenomenon? Pathol Res Pract. 1999; 195(6):413-9.

32. Frierson H.F., Cooper P.H., Myxoid variant of dermatofibrosarcoma protuberans. Am J Surg Pathol. 1983 Jul; 7(5):445-50.

33. Reimann J.D., Fletcher C.D., Myxoid dermatofibrosarcoma protuberans: a rare variant analyzed in a series of 23 cases. Am J Surg Pathol. 2007 Sep; 31(9):1371-7.

34. Ren W.M., Sheng W.Q., Wang J., Myxoid dermatofibrosarcoma protuberans: a clinicopathologic analysis of 16 cases. Zhonghua Bing Li Xue Za Zhi. 2012 Jul; 41(7):456--60.

35. Mentzel T., Schärer L., Kazakov D.V., Michal M., Myxoid dermatofibrosarcoma protuberans: clinicopathologic, immunohistochemical, and molecular analysis of eight cases. Am J Dermatopathol. 2007 Oct; 29(5):443-8.

36. Sato N., Kimura K., Tomita Y., Recurrent dermatofibrosarcoma protuberans with myxoid and fibrosarcomatous changes paralleled by loss of CD34 expression. J Dermatol. 1995 Sep; 22(9):665-72.

37. Nascimento A. F.., Hornick J. L., Tumors with Myxoid Stroma. In: Practical soft tissue pathology: a diagnostic approach (Hornick J. L. Ed) Elsevier Saunders, Philadelphia, 2013, p. 129-152.

Received February 10, 2015 